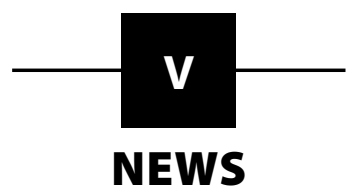

\title{
- Anthrocybib
}

AnthroCyBib, the Anthropology of Christianity Bibliographic Blog, was founded in October 2011 by Jon Bialecki (University of Edinburgh) and James Bielo (Miami University, Ohio). Naomi Haynes (University of Edinburgh) and Tom Boylston (London School of Economics) joined as co-curators of the site in November 2011 and March 2013, respectively.

The anthropology of Christianity is one of the fastest growing subfields in contemporary anthropology, and AnthroCyBib is a resource for those working in this field as well as the anthropology of religion more broadly. The site's main function is to post links to new articles, book chapters, volumes, and monographs as they are released. Because Christianity is attracting so much ethnographic and theoretical attention, staying up-to-date on new material is increasingly difficult. For this reason the curators find it valuable to have a single site where relevant work can be announced and searched via several tags (author, geographic area, variant of Christianity, theoretical focus, and key words).

In 2013 the site expanded to include book reviews, conference reports, and a teaching archive. The curators encourage reviews that creatively and provocatively engage theoretical and methodological conversations for the anthropology of Christianity. The Teaching Archive recognizes the close link between teaching and scholarship, and posts relevant syllabi from courses taught around the world. AnthroCyBib will continue to offer these resources, and in the future expand in other innovative, productive ways. More info at: http://anthrocybib.net/, and you can "Like" the site on Facebook: https://www.facebook.com/Anthrocybib.

\section{- IAHR World Congress Erfurt 2015}

The XXI Quinquennial World Congress of the IAHR (International Association for the History of Religions), hosted by the DVRW (German Association for the Study of Religions), will take place in Erfurt, Germany, 23-29 August 2015. The Congress theme is Dynamics of Religion: Past and Present, described as follows: "Religion is a human, historical, social, and cultural phenomenon. As such, religious ideas, practices, discourses, institutions, and social expressions are constantly in processes of change. The Congress will address the processes of change, the dynamics of religions past, present, and future, on several interconnected levels of analysis and theory, namely that of the individual, community and society, practices and discourses, beliefs, and narrations." These will be addressed within four areas:

- Religious communities in society: Adaptation and transformation

- Practices and discourses: Innovation and tradition

- The individual: Religiosity, spiritualities and individualization

- Methodology: Representations and interpretations 
Members of the Local Organizing Committee are:

Prof. Dr. Jörg Rüpke, Erfurt (Congress President)

Prof. Dr. Christoph Bochinger, Bayreuth (Congress President)

Prof. Dr. Tim Jensen, Odense (General Secretary of the IAHR)

Prof. Dr. Wanda Alberts, Hannover

Prof. Dr. Martin Fuchs, Erfurt

Prof. Dr. Vasilios Makrides, Erfurt

Prof. Dr. Hubert Seiwert, Leipzig

Prof. Dr. Katja Triplett, Marburg

Prof. Dr. Katharina Waldner, Erfurt

The Local Organizing Committee is supported by:

Dr. Elisabeth Begemann, Erfurt (Congress Coordinator)

Dr. Bernd-Christian Otto, Erfurt

\section{- Reverberations-New Directions in the Study of Prayer}

"Reverberations" is a new digital forum on prayer produced in conjunction with the Social Science Research Council's "New Directions in the Study of Prayer" initiative, which aims to generate innovative research on practices of prayer and to build an interdisciplinary network of scholars engaged in the study of prayer. Through a grants program led by a multidisciplinary advisory committee, the New Directions in the Study of Prayer initiative currently funds 28 scholars and journalists conducting research on practices of prayer throughout the world. The initiative is situated within the SSRC's program on Religion and the Public Sphere, and is supported with funding from the John Templeton Foundation. More info at: http://forums.ssrc .org/ndsp/.

\section{- Emory Forum for the Ethnographic Study of Religion}

The Emory Forum for the Ethnographic Study of Religion, convened by Professor Don Seeman, is devoted to intellectual exchange and promotion of research among diverse scholars, to the mentoring of students, and to the visibility of ethnography as a research method in the study of religion. To that end, we sponsor lectures by members of the Emory community and outside scholars, support one another's research, and contribute to the recruitment and training of students in each of our fields. Speakers during the first year of activities were Anderson Blanton (University of North Carolina), Marla Frederick (Harvard University), and Hillary Kaell (Concordia University). Recordings of parts of their presentations should be available soon.

All members of our extended academic and intellectual community are invited to participate. More information is available at http://gdr.emory.edu/academic_program/fesre-home .html. Students and faculty members who wish to be added to an email list for invitation to Ethnographic Forum events should please send an email with details of their interests, contact information, and affiliation to our student coordinator Cory Driver cory.driver@emory.edu, and "cc" Professor Don Seeman at dseeman@emory.edu. 


\section{- The Sociology of Islam Journal}

Edited by Gary Wood (Virginia Tech) and Tugrul Keskin (Portland State University) Sociology of Islam (SOI) provides an international scholarly forum for research related to the religion and culture of Islam, Muslim societies, and social issues related to Muslims in sociopolitical context. Decidedly rooted in the sociological perspective, SOI takes an expansive and global view of this broad subject matter. SOI publishes multiple issues per year containing original peer-reviewed articles and book reviews on the sociological, political, anthropological, historical, and other aspects of Islam and Muslim societies across all times and places. By promoting an academic understanding of the richly variegated and complex nature of both majority Muslim societies and of the issues related to the minority status of Muslims in other social contexts, in both thought and practice, Sociology of Islam makes a distinctive contribution to current scholarship in the field of sociology. More information is available at http://www.brill .com/publications/journals/sociology-islam. 